\title{
THE STUDY OF THE INDONESIAN PRAGMATIC PARTICLE SIH
}

\author{
Zainur Rofiq
}

zeinelfaqir@gmail.com

UIN Maulana Malik Ibrahim Malang

Indonesia

\begin{abstract}
Indonesian is a relatively particle-rich language used mostly in casual speech. However, the study on the pragmatic functions of the language is very few and indebted much solely to the works of Ikranagara (1975), Sari (2008), and of Wouk (1998 \& 2001). The present study aims to need to extend other functions of the particle sih in particular providing wider range of pragmatic functions than the previous work did. The data of the stuy derived from YouTube videos of live Indonesian unscripted talk show; and thus the conversations occur naturally during the program. The results reveal that marking an interrogative statement with sih following WH-words implies that the speaker emphasizes his main inquiry (e.g. 'where' emphasizes location) and urges the recipient to answer appropriately. Further, the study extends Sari (2008) and Wouk's (2006) findings that sih is not only used to emphasize the topic or main point of WH-interrogative statement, but also it applies to declarative statement.
\end{abstract}

Keywords: Indonesian language, pragmatic functions, particles, sih.

\section{INTRODUCTION}

Introductorily speaking, Bahasa Indonesia (henceforth: Indonesian) is a variety of standardized Malay that serves as a lingua-franca and is nationally recognized as an official language in Indonesian archipelago. Currently, it is spoken by nearly 160 million citizens, 140 million of whom speak it as an L2 after the local languages spoken among their communities. As a national language, Indonesian is used in educational institutions and governmental offices, while local languages are mostly used at home and in specific community gatherings, festivals, or ceremonies. Furthermore, Ikranagara (1975) described that it was Betawi, a dialect initially spoken by Jakartans that has much influenced casual speech of Indonesian. Presumably, it is due to the increasing number of TV programs starred by Betawi-speaking actors/actresses, that therefore the variant of Indonesian they speak may rapidly spread to other Indonesian speakers in various regions.
Despite the fact that Indonesian is a relatively particle-rich language used mostly in casual speech, this specific topic has remained less studied until recently. To the best of my knowledge, there have been three researchers to date who have studied Indonesian particles, Ikranagara (1975), Wouk (1998, 2001, \& 2006), Sari (2013), and Irham (2018) particularly in Madurese. Ikranagara seemed to be the pioneer in conducting a cross-linguistic analysis on a series of Indonesian particles (kek, kok, kan, $a h$, ye(ya), sih, dong, and deh) used in the script of folk play "Nyai Dasime" in the Betawi dialect. Besides mainly exploring lexical meanings of the particles in statements, orders and questions based on the context in the play, Ikranagara's work also presents some of their equivalents or counterparts in English. In the summary of his research (Ikranagara, 1975; pp. 105-106), he divides the basic meanings of the particles into two categories: the particles kok, kek, ah are used to express the speaker's feelings about a 
certain proposition, and the particles kan, $y e(y a)$, sih deh, dong indicate the violations of conversational postulates which have implications on politeness. Meanwhile, Wouk's (1998 \& 2001) papers investigated the particles $y a$ and kan in more detailed based on the recordings on the casual conversation of Indonesian. Overall, she draws a conclusion that the particles $y a$ and kan are used equally by both male and female speakers to build the solidarity in casual conversation of Indonesian. Additionally, Wouk (2006) analyzed the use of emotive (e.g. aduh, wah, astaga) and emphatic (e.g. deh, sih, nih) particles for apologizing in Lombok variant of Indonesian. Most recent study, furthermore, is conducted by Sari (2013) who anlyzed the prosodic aspect of particle sih in Indonesian corpora.

At larger context, studies on pragmatic particles in conversation have been pervasive in the past years. For instance, the analyses of 'well' and 'now' (Fraser, 1990; Aijmer, 2002; Defour, 2007) revealed that they are able to carry pragmatic meanings as "interpersonal function" (Traugott, 1999: 180) or as "topic changer" (Aijmer, 2002: 57-58). Besides, the research of the particle 'oh' and its locus in the conversation has been made explicit in several works (Heritage, 1984, 1998, 2013; Schiffrin, 1987). Heritage (2013) further emphasizes that the particle 'oh' can occur in first (as opening), second (as a response), and a third 'peripheral' position (as closing).

The present study is aimed at exploring the Indonesian particles sih. The selection is based on the fact that the particle is frequently used in spoken Indonesian according to the previous analyses (e.g. Ikranagara, 1975; Wouk, 1998; Sari, 2013); yet few of the pragmatic functions apparently need to be criticized and can be extended to express other functions depending on the contexts. More specifically, my analysis is mainly aimed at providing wider range of pragmatic functions of the particle sih as an extension to and evaluation for what have been suggested in the previous works.

The data used in this analysis are YouTube videos of live Indonesian unscripted talk show; therefore the conversations occur naturally during the programs. The cues of the spontaneity of conversations in the videos can be seen, for examples, from the laughter and hesitations made by the participants of the talks. The number of participants who involve in the talks is ranging from two, three, or even more participants.

The topics of the selected talks are related to the personal life of the participants and the other trending issues in Indonesia. I will limit myself to present the appropriate excerpts of talks as well as their contexts and provide their English translations. However, I will not quantify the occurrences of my data since the chief goal of this analysis is to provide additional functions and, if appropriate, argue against the current notions surrounding functions of particle sih.

\section{DISCUSSION}

\section{Previous Analyses of Particle Sih}

As cited in the introduction, there are a few scholars who have studied sih until the present time. Ikranagara (1975) pioneered a study on the folk script reveals the basic meanings of eight particles, including sih. His study shows that sih is used to express 'what is said by the speaker is true' in the declarative statement. Additionally, when used in interrogative statement, sih gives sense that the speaker is not really seeking an answer to his question or not assuming that the speaker must reply to it, which is then literally translated as 'I wonder'. Pertaining to this result, he emphasizes that the use of sih in question violates one of the basic conversational rules that the question must be answered.

Further, another study of sih is carried out by Wouk (2006) who analyzes its functions for apologizing language in Lombok. She describes that sih can help intensify the force of apology in conversation. The most recent study of sih is, perhaps, conducted by Sari (2013). She mainly analyzes the prosodic aspect of the particle and reveals that sih has two main intonations; rising and falling. Sih with rising intonation mainly occurs in the WH-interrogative statement which gives sense of emphasizing a specific matter being questioned and urgency for the recipient to come up with an answer to it. Meanwhile, falling intonation is used to emphasize the speaker's certainty of the topic in conversation.

Although it occurs very often in casual Indonesian, particle sih appears to have no 
equivalent in English, particularly, and therefore remains unstudied comparatively across languages. In contrast to sih, question tag-like particles, for example, seem to be functionally comparable across languages. Enfield and colleagues (2009) have studied Sentence-Final Particles (SFP) across three languages (Lao, Dutch, and Tzeltal) and show that the particles such as bi (in Tzeltal); bòò, $v a a$, and nòq (in Lao), toch and hè (in Dutch) can function as agreement seekers or a request for verification and confirmation for the speaker's assertion. Wouk (1998) also employs a comparative approach to study Indonesian kan as tag-like and 'you know' particle.

\section{Functions of Sih Contrastive Marker}

Example (1) is a talk between DC and NS about NS's life as a housewife (also mother) and famous TV presenter. NS told DC that she just lost her baby, and then DC asked her whether she blamed God for losing her premature baby-daughter, who died after a few hours of her birth. In this responsive statement, instead using the responsive marker either 'iya/ya' 'yes' or 'tidak/nggak' 'no' in English to reply DC's question, she directly made a statement that she blamed herself for this loss by marking sih finally. In this context, sih is used to contrast and implicitly negate the DC's proposition since on one hand it is morally unacceptable to affirm the DC's assertion and, on the other hand, it is also fully uneasy to put blame on herself considering the maximum efforts she had already made. In other words, sih can be used in responsive statement to contrast the asker's proposition when the replier is in uneasy and dilemmatic situation to respond.

(1) DC: Do you blame God at that time?

NS: Saya menyalahkan diri sendiri sih.

I blame self alone sih.

DC: Do you blame God at that time?

NS: (No), I blame myself for it instead.

\section{Expressing Emphaty}

Another function of sih is expressing an emphatic statement and the speaker's feeling. It is typically expressed either in lowered or high intonation, depending on how much speaker's emotion being evoked. As illustrated in example (2), DC is told by D that NS is friendly. However, DC assumes that NS was pretending to care and be friendly to $\mathrm{D}$ because NS might not have another friend. NS' statement marked by sih here expresses sense of emphaty if it were really the case happening to her.

(2) DC: Mungkin gak punya teman, makanya liat kamu 'wah ini bisa jadi teman gue ini'.

Maybe not have friend thus see you intr. this can become friend I this

NS: Kasian amat sih

Pity really sih

DC: (she) might have no other friend; therefore (she) made friendship with you.

NS: how pity I was (if it were really true).

\section{Speaker's View of Truth}

Example (3) illustrates that sih seems to give sense of uncertainty and doubt of the truth of the hearsay. In the last segment of the talk show, DC invites another guest star who knows NS' teenage life. Before revealing who the next guess is, DC tells NS that the next guess, according to hearsay, knows her well. By marking hearsay' with sih, it enables DC to doubt the truth of the information he heard. Comparing example (3) to (4), it seems that sih expresses the speaker's viewpoint of the truth of information.

(3) DC: ini kenal dekat katanya sih...katanya...

This know close hearsay sih hearsay

NS: siapa...siapa...?

Who who

DC: this (guest) knows you well according to hearsay (but I am not sure).

NS: who is he?

(4) DC: saya dengar-dengar dari...dari...e...katanya lo ngefan banget sama R?

I hear.repeated from from e hearsay you fan really with R?

LM: [laugh]...R...iya suka, lucu. [laugh] $\mathrm{R}$ yes like cute. 
DC: I heard from hearsay that you are really a fan of $\mathrm{R}$, right?

LM: [laugh]......yes I am, (he is) cute.

\section{Emphasis}

It seems that $\operatorname{sih}$ can also serve as emphasis in either interrogative or declarative statements. When WH-question is marked by sih, it emphasizes the point being questioned and, thus, it urges the recipient to reply the speaker's question. Meanwhile, marking sih into a declarative statement seems to emphasize the truth of the assertion. In example (5) DC and LM involve in conversation about the gossip in the social media that LM is close to a younger risingactor. Therefore, DC poses some questions for LM and emphasizes that he urges her to come up with answers. In example (6), DC and LM involve in a talk about the emerging trend of match-making agency. DC tells her that the next guest will talk about it. Eventually, LM emphasizes that she does not need such an agency because, as she previously tells LM, she has a boyfriend now.

(5) 1 DC: Ap

2 LM: Cakep handsome

3 DC: Apa cakepnya sih? (1.0) What handsome sih

\section{LM: Kenapa sih?} Why sih?

5 DC: ya nggak apa-apa Yeah not what.repeated

(6) DC: Bintang tamu saya ini kerjanya adalah mencarikan pasangan

$\begin{array}{lrrr}\text { Star } & \text { guest } & \text { I } & \text { this } \\ \text { work } & \text { is } & & \text { find } \\ \text { couple } & & & \end{array}$

LM: Oh gitu..yah, saya udah nggak perlu sih. Int. that yeah I already not need sih

DC: My next guest star works as a match-making agency.

LM: Oh..but I really do not need it (now).

In the line 1,3 , and 4 in the excerpt above show that sih seems to serve as emphasis to the main point being questioned and urgency for the recipient to provide appropriate answers to it.

\section{Wonder}

The following example illustrates that sih can express a sense of the speaker's wonder or surprise in conversation. Example (7) has similar context with (6) in which LM thinks that DC might need a match-making agency to help him find a couple as he got divorced recently. The use of sih here provides sense of the speaker's wondering of the unexpected statement or condition from his conversant. It is quite common in casual Indonesian that particle kok 'surprise' occurs together with sih to express the speaker's wondering.

(7) LM: Mungkin [pointing to DC] perlu kayaknya.

Maybe need seem

DC: kok anda tau sih

Part. You know sih.

LM: perlu

Need

LM: (I think) you need it

DC: (oh, how) you know it? (I just wonder and get surprised)

LM: you do

\section{Positions of Sih}

It is quite difficult to map a definite position of sih and associate it with a particular function in the conversation. However, in general, sih can occur in the final position of a statement as in example (1) repeated here as (8), or follow WH-words (9), or occur between predicate and object as in (10). Although I do not find its occurrences in my data, it is quite common that sih also can occur in initial position, especially for Eastern Java variant of spoken Indonesian as illustrated in a fabricated example (11). When sih occurs in such a slot, it provides sense of the speaker's surprise.

(8) NS: Saya menyalahkan diri sendiri sih.

I blame self alone sih. '(No), I blame myself for it instead'

(9) DC: Sebenarnya dilarang kenapa sih? Actually forbid why sih? 
'Actually, why are you forbidden (to love her)?' (I urge you to answer me)

(10) D: Mungkin orangtua pengennya sih yang terbaik ya.

Maybe parents want

sih rel. best yeah

'parents might want the best (man for me)'

*(11) Sih, cantik anak kamu ya.

Sih beautiful child you yeah.

'your daughter is beautiful right' (I am surprised!)

\section{CONCLUSION}

Ikranagara (1975) has suggested that particle sih is mainly used to express 'what is said by the speaker is true' in declarative statement, which corresponds to my finding in the present paper. Furthermore, he also finds that, when sih is used in interrogative statements or when it occurs following $\mathrm{WH}$ words, it gives sense that the speaker is merely wondering about the subject under question and he does not require that the recipient answer his question. In contrast, based on my data, I will argue that marking an interrogative statement with sih which follows $\mathrm{WH}$-words can give the sense that the speaker emphasizes his main inquiry (e.g. 'where' emphasizes location) and urges the recipient to answer appropriately.

My data confirm the functions of $s i h$ suggested by the previous works and offer another functional description of it. My finding extends Sari (2008) and Wouk's (2006) finding that sih is not only used to emphasize the topic or main point of $\mathrm{WH}$-interrogative statement, but also it applies to declarative statement as in examples (5) and (6). Besides, the present analysis also confirms Wouk's (2006) conclusion that sih serves as emphatic particle as in example (2) and can be used to express the speaker's view of the information truth, as illustrated in examples (3) and (4). Eventually, the present study also shows that sih can be used as a contrastive marker when the speaker feels uneasy to fully negate or accept his partner's proposition as illustrated in example (1).

Generally, in relation to the positional distribution in the talks, sih can occupy three main slots. Sih can assume final position of a statement or independent clause, come after
WH-words in interrogatives, or occur between predicate and object. Although my data and previous studies do not suggest that sih can occur in initial position, Indonesian spoken in a few regions in East Java shows flexibility of sih to occupy the left-most periphery, as illustrated in a fabricated example (11). When sih occurs in initial position, it typically expresses the speaker's surprise in conversation.

In sum, the present study has confirmed and extended functional descriptions of $s i h$ in spoken Indonesian. The use of sih enables the speaker to emphasize the topic in conversation, express his views and assessment of the information truth, and express the speaker's feeling into the conversation. Therefore, it is obvious that understanding the functions of sih and other Indonesian discourse particles will enable speakers of the language to achieve communicative goals in their spoken communication. 


\section{REFERENCES}

Aijmer, K. (2002). English discourse particles: Evidence from a corpus. Philadelphia: John Benjamins Pub. Co

Defour, T. (2007). A Diachronic Study of the Pragmatic Markers "well" and "now". (Unpublished doctoral dissertation). University of Ghent, Ghent.

Enfield, N. J., Brown, P., de Ruiter, J. P. (2009). Epistemic dimension of polar questions: Sentencefinal particles in comparative perspective. In J. P. de Ruiter (Ed.), Questions: Formal, Functional and Interactional Perspectives (pp.193-221). New York: Cambridge University Press.

Fraser, B. (1990). An approach to discourse markers. Journal of Pragmatics, 14(3), 383398.

Heritage, J. (1984). A change-of-state token and aspects of its sequential placement. In J. M. Atkinson \& J. Heritage (Eds.), Structures of Social Action. Cambridge, Cambridge University Press.

Heritage, J. (1998). Oh-prefaced responses to inquiry. Language in Society, 27, 291-334.

Heritage, J. (2013). Turn-initial position and some of its occupants. Journal of Pragmatics, 57(3), 331-337.

Ikranagara, Kay. (1975). Lexical Particles in Betawi. Linguistics, 165, 93-108.

Irham, I. (2018). EVALUATING THE PRAGMATIC PARTICLE JÂ' IN A MADURESE SPOKEN CORPUS. $\begin{array}{llll}\text { Indonesian Journal of Applied } & \text { Linguistics, }\end{array}$ doi:https://doi.org/10.17509/ijal.v7i3.9814

Sari, Faizah. (2008). A prosodic aspect of the Indonesian pragmatic particle sih. Abstract submission for ISMIL 13. http://wwwstaff.eva.mpg.de/ gil/ismil/13/abstracts/Faizah\%20abstract\%20ISMIL\%2013. pdf retrieved July $1^{\text {st }}, 2017$.

Schiffrin, D. (1987). Discourse markers. Cambridge: Cambridge University Press.

Traugott, E. C. (1999). The rhetoric of counterexpectation in semantic change: a study in subjectifícation. In A. Blank, \& P. Koch. (eds.), Historical semantics and cognition. Berlin: Mouton de Gruyter.

Wouk, Fay. (1998). Solidarity in Indonesian conversation: The discourse marker kan. Multilingua. 17: 381-408.

Wouk, Fay. (2001). Solidarity in Indonesian conversation: The discourse marker ya. Journal of Pragmatics. 33: 171-191.

Wouk, Fay. (2006). The language of apologizing in Lombok, Indonesia. Journal of Pragmatics. 38 : 1457-1486. 